\title{
Assessment of Wood Surface Quality Obtained During High Speed Milling by Use of Non-Contact Method
}

\section{Upotreba beskontakne metode za ocjenu kvalitete površine drva nakon visokobrzinskog blanjanja}

\author{
Original scientific paper • Izvorni znanstveni rad \\ Received-prispjelo: 23. 8. 2010. \\ Accepted-prihvaćeno: 25. 2. 2011. \\ UDK: $630 * 823.121$ \\ doi:10.5552/drind.2011.1027
}

\begin{abstract}
This paper presents the method of surface quality evaluation at high-speed milling of wood. The effects of specific parameters of machining on the surface quality are described and results are presented of experiments carried out on selected tree species, where the effects of specific parameters on the surface quality were noted. The surface quality is evaluated by a non-contact method using a confocal sensor (CLA), which processes the results of the roughness measurement, Talysurf CLI 1000. It can be concluded that this method could actually be used for the evaluation of the surface quality.
\end{abstract}

Keywords: high-speed milling, wood surface quality, roughness, waviness, shape, filter

SAŽETAK • U radu se analizira metoda za ocjenu kvalitete površine drva nakon visokobrzinskog blanjanja. Opisan je utjecaj pojedinih parametara obrade na kvalitetu površine drva i izneseni su rezultati mjerenja kvalitete površine nakon eksperimentalnog blanjanja izabranih vrsta drva. Kvaliteta površine drva ocijenjena je beskontaktnom metodom uz pomoć konfokalnih senzora (CLA) koji procesuiraju rezultate mjerenja hrapavosti. Mjerenje hrapavosti obavljeno je uređajem Talysurf CLI 1000. Zaključeno je da postoji realna mogućnost primjene prezentirane beskontaktne metode za ocjenu kvalitete površine drva.

Ključne riječi: visokobrzinsko blanjanje, kvaliteta površine drva, hrapavost, valovitost, kontura, filtar

\section{INTRODUCTION \\ 1. UVOD}

Milling is a technological process used for making the surface of certain shape, dimensions and quality cutting material particles (chips) or wood fibre bundles (cutting operation). Fig. 1 shows the kinematics of cutting a chip in standard milling (conventional milling). In practice, however, the actual chip cross-section can differ from the nominal cross-section due to blunting, inaccurate spindle run, deviations of cutting edges from the cutting circle, irregularities of the feeding device cycle and, particularly, due to splitting off and heterogeneity of the workpiece material.

\footnotetext{
${ }^{1}$ Authors are PhD student, professor and assistant professor at Faculty of Forestry and Wood Technology, Mendel University, Brno, Czech Republic.

Autori su student doktorskog studija, profesor i docent na Fakultetu šumarstva i drvne tehnologije Mendelova sveučilišta, Brno, Republika Češka.
} 


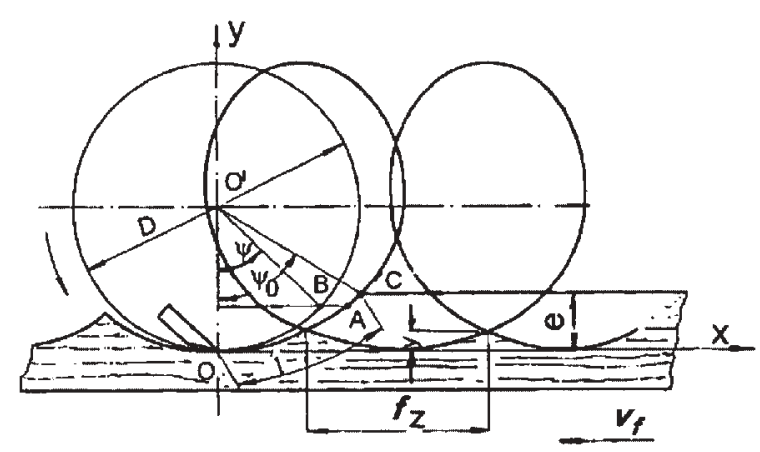

Figure 1 Milling of wood workpieces

Slika 1. Blanjanje drvenog obratka

The tool edge trajectory creates a cycloid curve, cutting speed being, however, very high at higher diameters of milling tools in proportion to the feed rate. Thus, at the section of the edge cut, it can be supposed with high probability that its cutting track will form a circle.

The problems of milling and machining surface quality have already been thoroughly investigated. The paper is based on findings of authors and their publications (Lisičan, 1996; Prokeš, 1965) and some other foreign and Czech authors.

The process of chip production shows a fundamental effect on the workpiece surface quality. So, it can be quite well described by relationships (1) and (2) resulting from Fig. 2.

Problems of machining are dealt with by Koch (1964). Problems of high-speed machining have been discussed recently. Lichtág et al. (2003) lay out in their research report an opinion of the general division of machining to normal, high-speed and extreme (Fig. 3) specifying a limit between normal and high-speed machining according to the relation (3). For the field of high-speed machining, they mention the rate $v_{\mathrm{c}}=70-$ $130 \mathrm{~m} / \mathrm{s}$.

According to Prokeš (1965), decisive importance for the quality of a machined surface is shown by the size of feed per tooth (see equation 4). Problems of measuring the surface roughness using a contact method are dealt with by Škaljić et al. (2009). The authors give results of measuring surface quality with samples of four wood species.

Svoboda et al. (2009) deal with the application of a non-contact method and lay out that the method can be

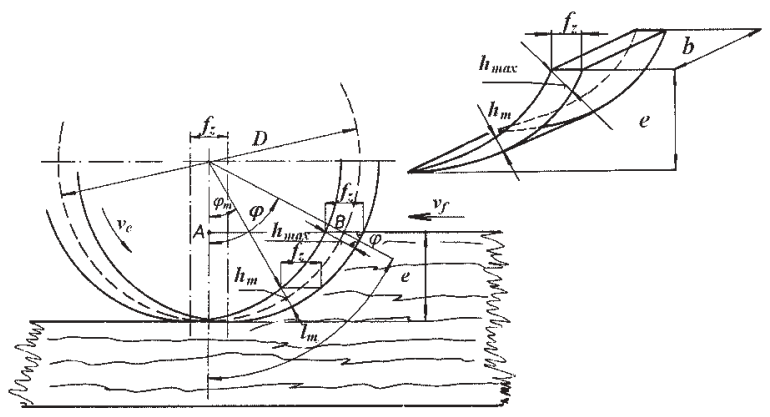

Figure 2 The scheme of cutting chips by cylindrical milling cutter

Slika 2. Shema odvojene čestice pri blanjanju drva cilindričnom glavom za blanjanje

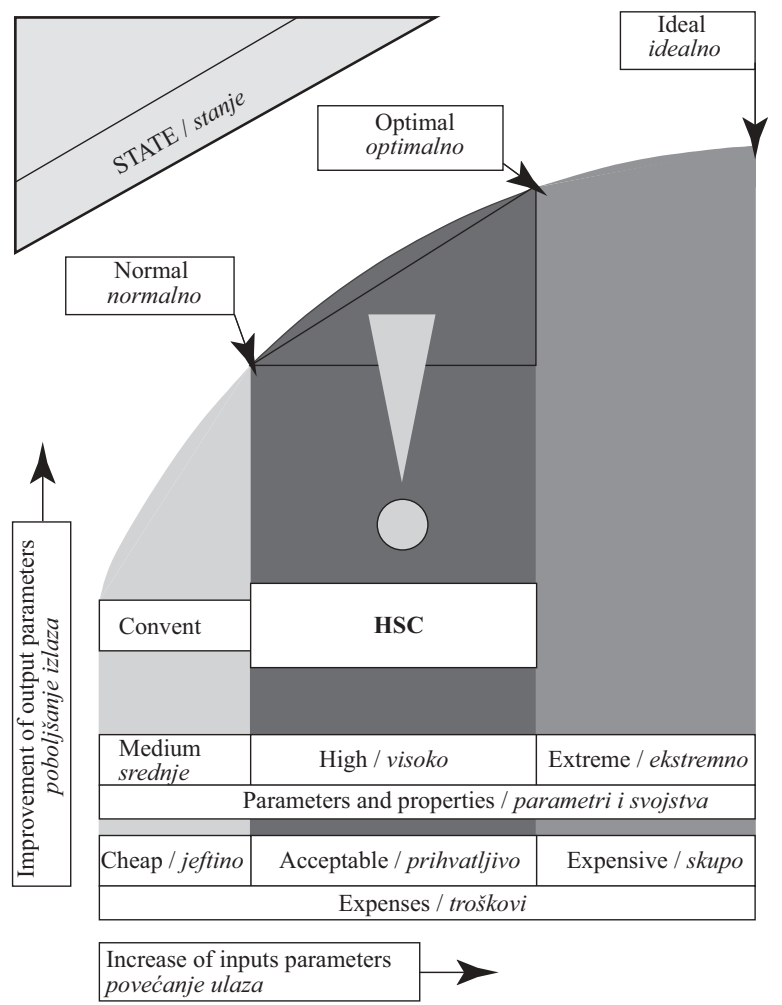

Figure 3 The scheme depending on inputs and outputs for high-speed milling

Slika 3. Shema obilježja visokobrzinskog blanjanja

used for the evaluation of roughness and waviness of the wood surface. The paper of Kowalski et al. (2008), where modelling the surface geometrical structure originating in the process of wood milling is discussed at a theoretical level, is rather inspiring. Sandak (2008) dealt with the problem similarly. After a theoretical analysis, he used the non-contact method of measurement to evaluate the surface quality. Using the laser sensor for surface inspection is discussed in a paper by Barcík et al. (2009), where differences determined between the surface quality of juvenile and mature wood are presented. A laser sensor of the surface profile was also used in a paper by Siklienka et al. (2008) at surface roughness quantification in cutting by horizontal band saw.

The theoretical mean chip thickness $\left(h_{\mathrm{m}}\right)$ is the function of feed per tooth $\left(f_{\mathrm{z}}\right)$. For its determination the following relations can be used:

$$
\begin{gathered}
h_{\mathrm{m}} \approx f_{\mathrm{z}} \cdot \sin \varphi_{\mathrm{m}} \\
\varphi_{\mathrm{m}} \approx \frac{1}{2} \arccos \left(1-\frac{e}{R}\right)
\end{gathered}
$$

where:

$h_{\mathrm{m}}$ - mean chip thickness / srednja debljina strugotine, $\mathrm{mm}$

$f_{\mathrm{z}}$ - feed per milling head edge / zahvat po oštrici alata, $\mathrm{mm}$

$\varphi_{\mathrm{m}}$ - average angle / srednji kut zahvata, ${ }^{\circ}$

$R$ - cutting edge radius of a milling head / polumjer

kružnice koju opisuju rezne oštrice, $\mathrm{mm}$

$e$ - cutting depth / dubina blanjanja, mm

Cutting speed:

$$
v_{\mathrm{c}}=\frac{\pi \cdot D \cdot n}{60 \cdot 1000}
$$




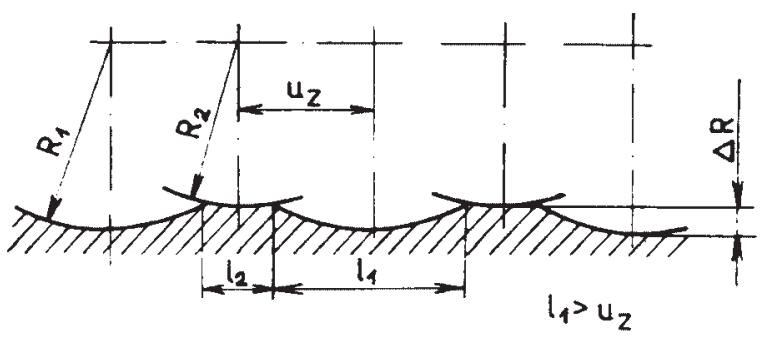

Figure 4 The workpiece surface in case of inaccurate setting of knives

Slika 4. Površina obratka pri netočno postavljenim noževima

Feed per tooth:

$$
f_{\mathrm{z}}=\frac{v_{\mathrm{f}} \cdot 1000}{n \cdot z}
$$

where:

$v_{\mathrm{c}}$ - cutting speed / brzina rezanja, $\mathrm{m} / \mathrm{s}$

$n$ - tool revolutions / frekvencija vrtnje alata, $\min ^{-1}$

$D$ - cutting edge diameter of a milling head / promjer kružnice koju opisuju rezne oštrice, $\mathrm{mm}$

$v_{\mathrm{f}}$ - feed speed / posmična brzina, $\mathrm{m} / \mathrm{min}$

$z$ - number of edges of a milling head / broj oštrica

Considering the fact that the milling cutter edge creates a circle, it is possible to determine the theoretical depth of the surface roughness $(y)$ of milled surfaces up to hundredths of $\mathrm{mm}$. Then, a known relationship can be accepted to determine the wave theoretical depth $y$ :

where:

$$
y=\frac{f_{z}^{2}}{4 \cdot D} \Rightarrow f_{\mathrm{z}}=\sqrt{4 \cdot D \cdot y}
$$

$y$ - depth of the surface kinematical roughness / dubina površinske kinematičke hrapavosti, $\mathrm{mm}$

The relation (5) applies to absolutely accurate setting of the milling head knives. In practice, it is often rather difficult to set up milling heads into a cutting edge with absolute accuracy. Thus, a situation shown in Fig. 4 can occur, if we know that $R=D / 2$.

Characteristic factors determining the surface quality of a milled workpiece are as follows: tree species, volume weight, mechanical properties, moisture content, and orientation of wood fibres with respect to

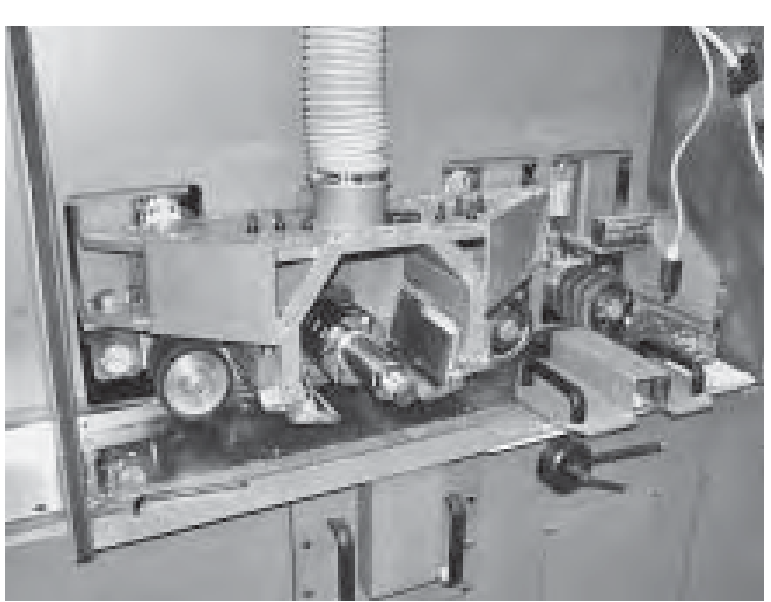

the direction of the cutting edge movement. For the purpose of this paper it is sufficient when these factors are expressed by the tree species and its moisture content. The optimum moisture of wood is $8 \pm 2 \%$.

Kinematic roughness is the result of mutual motion of a milling head and a workpiece. The rotational motion of a milling cutter and usually the straight-line shift of a workpiece cause typical surface roughness cycloid waves. The waves are characterized by their depth and the distance of their tops. This type of regular inequality is termed as waviness. Roughness arising from the wood structure results from the non-homogenous structure of wood and different behaviour of early and late wood during machining. It is assessed as irregular waviness. Picking-up the wood fibres is also related to the wood structure and behaviour. Torn bundles of wood fibres and microscopic and macroscopic cavities on the wood surface are characterized by their roughness (smoothness). The occurrence of this roughness is mostly irregular on the tooled surface.

\section{MATERIAL AND METHODS} 2. MATERIJAL I METODE

Samples of Norway spruce (Picea abies) and beech (Fagus sylvatica) were milled on an experimental stand.

Parameters of milling on the experimental stand were selected in two regimes:

1. spindle speed: $9000 \mathrm{~min}^{-1}$, feed speed: 18, 20 and $22 \mathrm{~m} / \mathrm{min}$ and chip removal: $2 \mathrm{~mm}$ resulting in sample thickness of $42 \mathrm{~mm}$

2. spindle speed: $10000 \mathrm{~min}^{-1}$, feed speed: 18,20 and $22 \mathrm{~m} / \mathrm{min}$ and chip removal: $2 \mathrm{~mm}$ resulting in sample thickness of $42 \mathrm{~mm}$

Tool parameters:

- milling head: $125 \mathrm{~mm}$ in diameter, $100 \mathrm{~mm}$ in width,

- number of knives: 6 , shaft (spindle) bore $\varnothing 40 \mathrm{~mm}$

The process of sensing the milling machine parameters:

- parameters (spindle speed, spindle motor current, speed of feed cylinders, motor currents of feed cylinders)

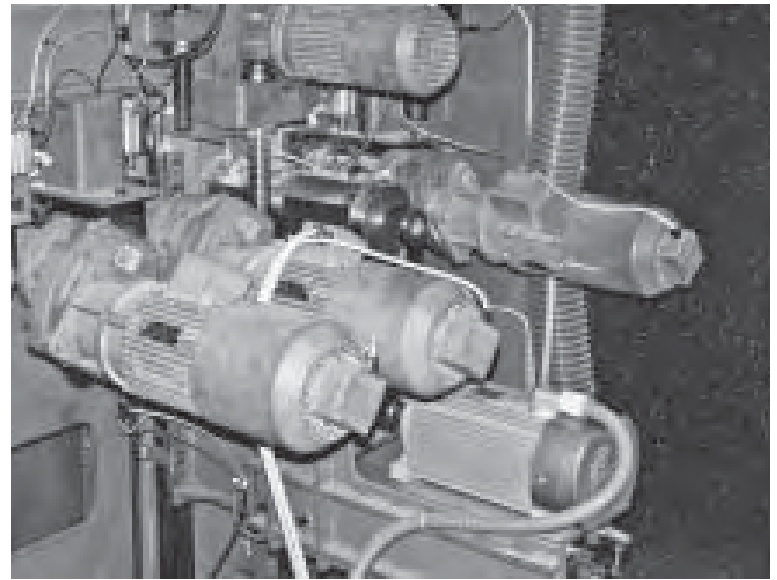

Figure 5 Experimental stand - a view of the workplace and motor place

Slika 5. Prikaz stroja za eksperimentalno blanjanje, radni i pogonski dio 


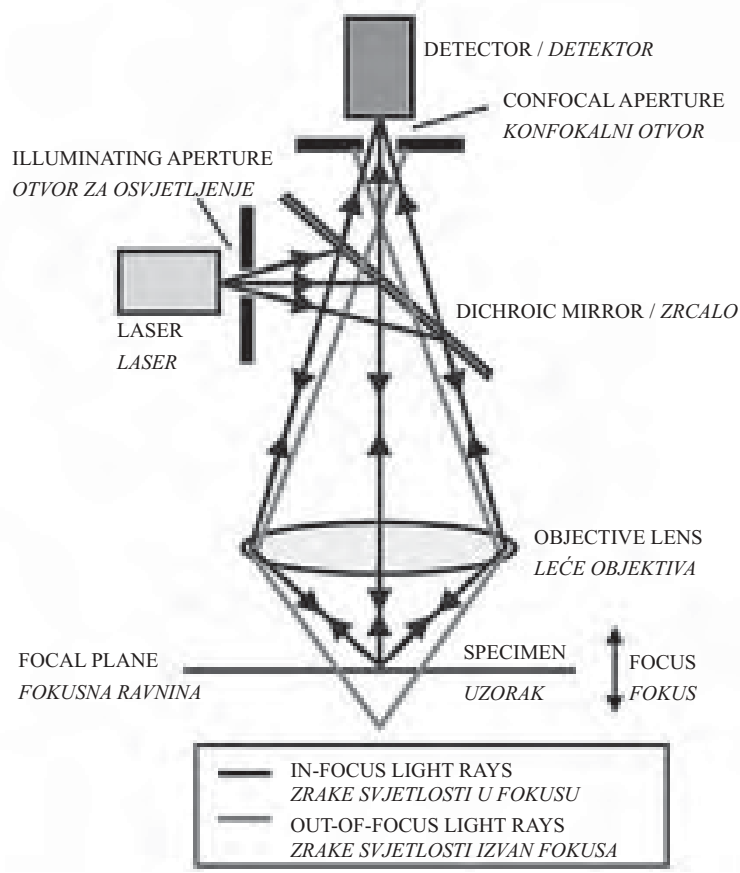

Figure 6 The principle of a raster confocal microscope Slika 6. Načelo rada točkastoga konfokalnog mikroskopa http://fyzika.fce.vutbr.cz/file/kusak/konfokalni_mikroskopie.pdf

- sampling time: $10 \mathrm{~ms}$

- measurement time: $15 \mathrm{~s}$.

For the surface evaluation, an optical method was used based on the surface topography by a non-contact confocal sensor CLA (Chromatic Length Aberration), which is part of a system for the surface texture evaluation (Talysurf CLI 1000). This system can carry out evaluation of the 2D (in total 117 parameters) and 3D (in total 40 parameters) surface structure.

Laser beam (intensive laser point source of light) is focused on a diaphragm, and it goes through the object lens up to a sample, where the diaphragm image is focused into a point whose diameter corresponds to the diffraction limit (differential limit).

Also, light reflected or scattered on the sample goes by return through the same object lens or fluorescence occurs.

Secondary light going back passes again through a diaphragm whose point image is localized by the beam divider through a photomultiplier (PMT), where



the second confocal point diaphragm is placed, which filters light coming from an area outside the microscope focal plane.

An image of the whole focused plane can be obtained through stepwise scanning using some of the following procedures: wobbling a laser beam, transverse feed of a sample before object lens, the object lens feed over the sample.

Methods of the surface quality evaluation by Talysurf CLI 1000:

1. Levelling the surface - levelling the surface according to the selected area

2. Zoom - the selection of an area from the measured surface for further adjustments and analyses

3. Form removal - used for the geometrical shape separation in measuring the actual surfaces

4. Thresholding-including the corresponding spectrum of data into analysis

5. Obtaining the basic area

6. Filtration - obtaining the area of waviness and roughness

7. Depiction of the 3D area

8. Determination of 3D parameters of the area surface structure

The surface of milled samples was evaluated using the following parameters:

$S$ parameter - the surface amplitude parameter

$R$ parameter - a parameter calculated from the roughness profile

$W$ parameter - a parameter calculated from the waviness profile

Gaussian filters of 0.8 and 2.5 were used for roughness and waviness parameters.

\section{RESULTS AND DISCUSSION} 3. REZULTATI I RASPRAVA

The results of the surface quality measurement were processed using the Talymap program in Talysurf system (see Fig. 8). An example is given of the 3D image of a beech sample, data on roughness and waviness and a selected section of the $2 \mathrm{D}$ basic profile, waviness profile and roughness profile.

Through the processing of data, waviness parameters can be obtained that can be compared with

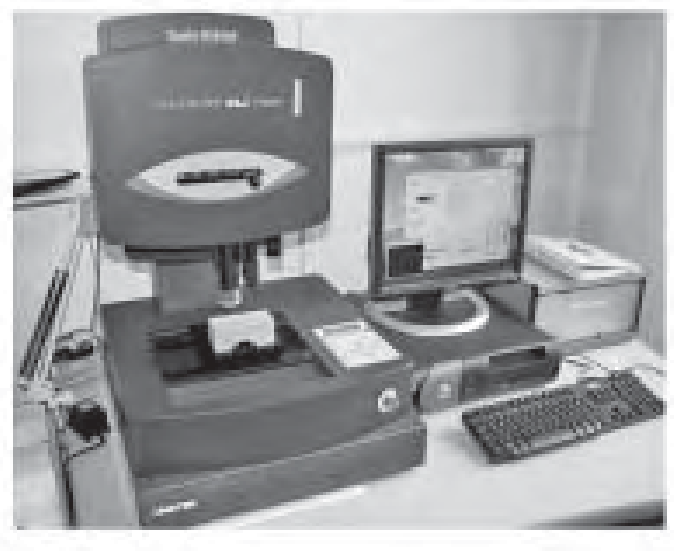

Figure 7 Evaluation of the surface quality byTalysurf CLI 1000

Slika 7. Ocjena kvalitete površine upotrebom uređaja Talysurf CLI 1000 




Roughness Parameters, Gaussian filter, $0,8 \mathrm{~mm}$ Parametri hrapavosti, Gaussov filter, 0,8 $\mathrm{mm}$

$$
\begin{array}{ll}
R_{\mathrm{a}} & =4.17 \mu \mathrm{m} \\
R_{\mathrm{q}} & =5.15 \mu \mathrm{m} \\
R_{\mathrm{t}} & =30.6 \mu \mathrm{m} \\
R S_{\mathrm{m}} & =0.345 \mathrm{~mm} \\
R_{\mathrm{z}} & =18.4 \mu \mathrm{m}
\end{array}
$$

Waviness Parameters, Gaussian filter, $0,8 \mathrm{~mm}$ Parametri valovitosti, Gaussov filter, $0,8 \mathrm{~mm}$

$$
\begin{array}{ll}
W_{\mathrm{a}} & =4.47 \mu \mathrm{m} \\
W_{\mathrm{g}} & =5.03 \mu \mathrm{m} \\
W_{\mathrm{t}} & =28.4 \mu \mathrm{m} \\
W_{\mathrm{m}} & =1.84 \mathrm{~mm} \\
W_{\mathrm{z}} & =11.1 \mu \mathrm{m}
\end{array}
$$

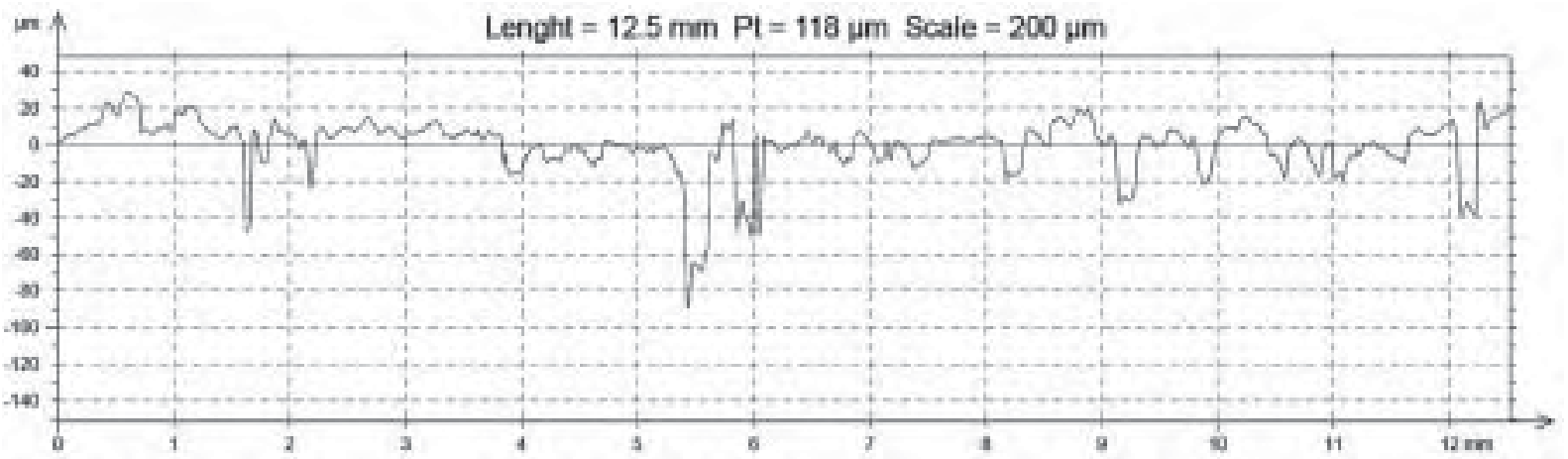

2D basic profile / 2D osnovni profil

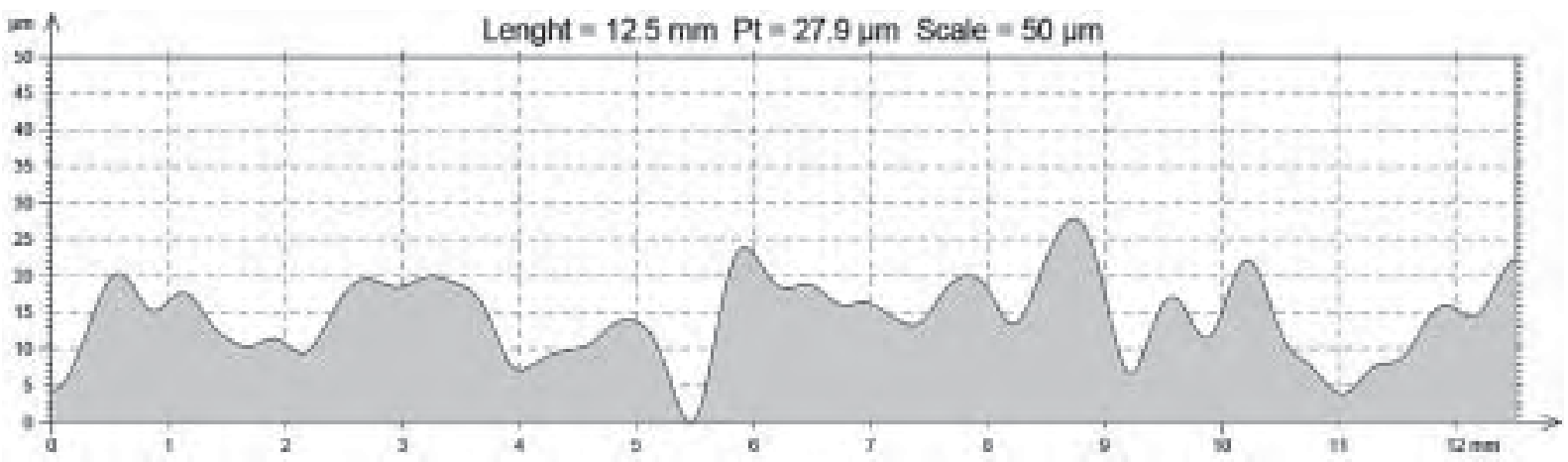

2D waviness profile / $2 D$ profil valovitosti

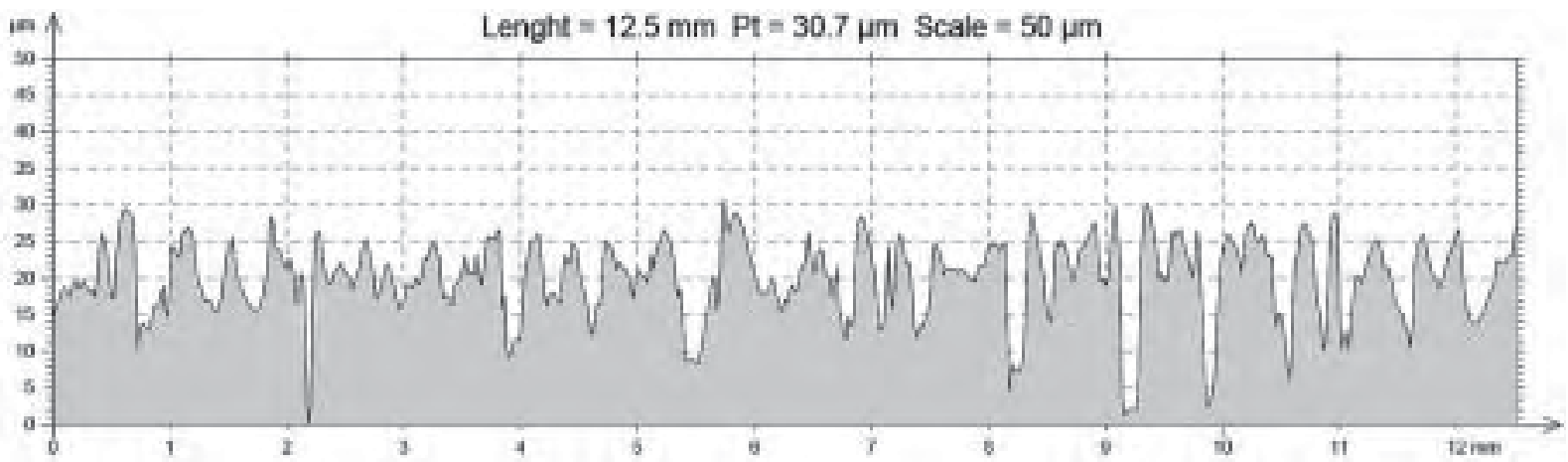

2D roughness profile / $2 D$ profil hrapavosti

Figure 8 Basic data on the surface quality of a beech-wood sample from a PC

Slika 8. Osnovni podaci o kvaliteti površine bukovih uzoraka dobivenih na računalu 
theoretically calculated values. Fig. 9 illustrates that the actual length of waves is higher than the theoretical value. Thus, an assumption is proved that all knives are not in gear.

The measured parameters of the surface quality were then processed in the form of well-arranged tables. Only changes of the waviness parameters $\mathrm{Wz}$ (Fig. 10) were processed in diagrams. Data on roughness were processed in the same way.
By parameters of waviness it is possible to monitor kinematic unevenness, i.e. the process of high-speed milling, changes during machining, machine and tool instability, changes in the operation of a cutting tool. By roughness parameter it is possible to monitor the effects of particular species on the surface quality or chipped (torn) grain.

The mean arithmetic deviation of parameters of waviness $\mathrm{Wa}$ ranges from $4.27 \mu \mathrm{m}$ at $9000 \mathrm{~min}^{-1}$ to

Annual ring - summer wood / god - kasno drvo

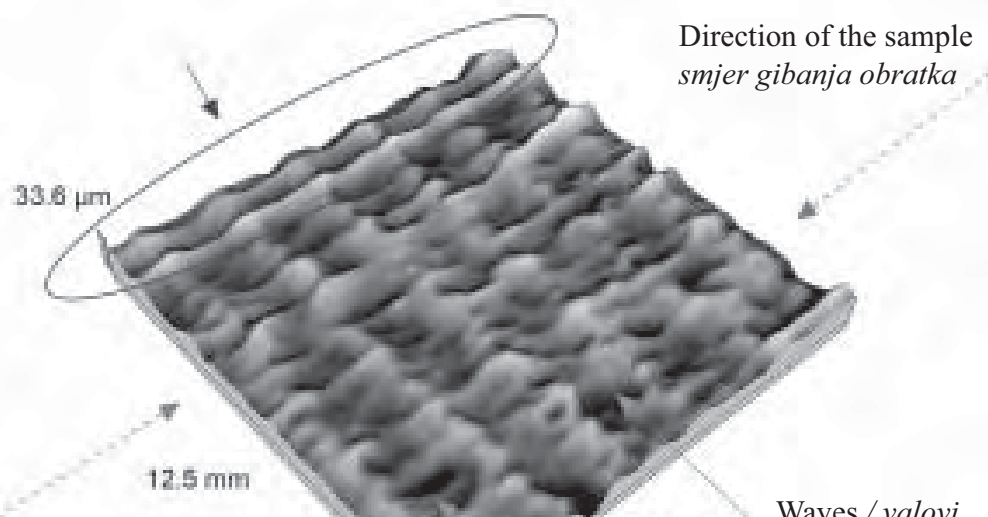

Direction of the tool turning smjer vrtnje alata

$12.5 \mathrm{~mm}$

Waves / valovi

Wave top / vrh vala

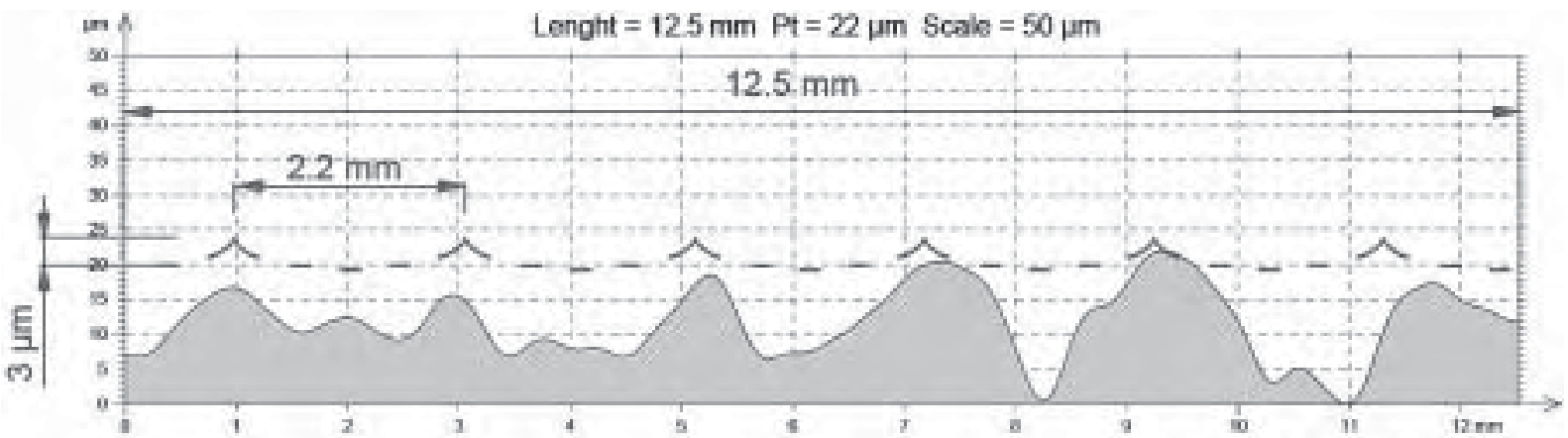

The actual distance of waves $-2 \mathrm{D}$ profile of waviness ( $\mathrm{mm}$ is the unit of axis $x$ and $\mu \mathrm{m}$ of axis $y$ )

Stvarna udaljenost valova - 2D profil valovitosti (skala na osi $x$ iskazana je u mm, a na osi y u $\mu \mathrm{m}$ )

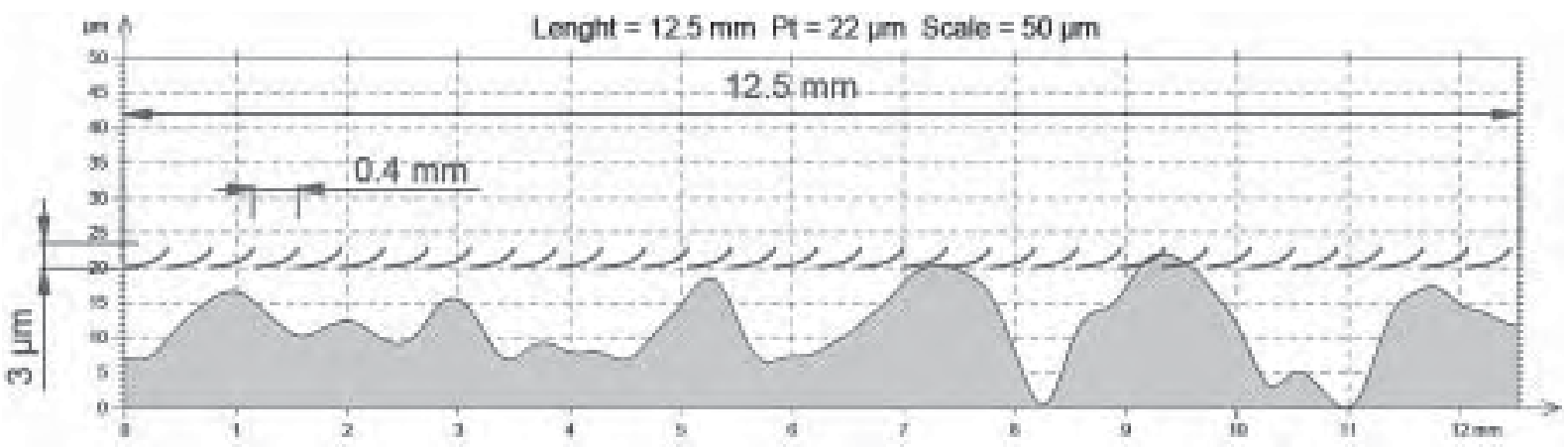

The theoretical distance of waves -2D profile of waviness ( $\mathrm{mm}$ is the unit of axis $x$ and $\mu \mathrm{m}$ of axis $y$ )

Teorijska udaljenost valova -2D profil valovitosti (skala na osi $x$ iskazana je u mm, a na osi y и $\mu \mathrm{m}$ )

Figure 9 The profile of waviness of spruce at $9000 \mathrm{~min}^{-1}$, feed $20 \mathrm{~m} / \mathrm{min}$

Slika 9. Profil valovitosti smrekovih uzoraka pri frekvenciji vrtnje alata $9000 \mathrm{~min}^{-1}$ i posmičnoj brzini $20 \mathrm{~m} / \mathrm{min}$ 
Table 1 Values of roughness and waviness of experimental spruce-wood samples

Tablica 1. Vrijednosti hrapavosti i valovitosti uzoraka od smrekovine

\begin{tabular}{|c|c|c|c|c|c|c|c|}
\hline \multicolumn{8}{|c|}{ Spruce-wood samples / Uzorci od smrekovine } \\
\hline \multirow{2}{*}{\multicolumn{2}{|c|}{$\begin{array}{l}\text { Rotational speed, } \text { min }^{-1} \text { / Brzina vrtnje, } \text { min }^{-1} \\
\text { Feed speed, m/min / Posmična brzina, } \mathrm{m} / \mathrm{min}\end{array}$}} & \multicolumn{3}{|c|}{$9000 \mathrm{~min}^{-1}$} & \multicolumn{3}{|c|}{$10000 \mathrm{~min}^{-1}$} \\
\hline & & 18 & 20 & 22 & 18 & 20 & 22 \\
\hline \multirow{4}{*}{$\begin{array}{l}\text { Parameters of the basic area } \\
\text { Parametri osnovne površine }\end{array}$} & $S_{\mathrm{a}}, \mu \mathrm{m}$ & 9.55 & 9.13 & 9.23 & 9.30 & 8.18 & 7.99 \\
\hline & $S_{\mathrm{q}}, \mu \mathrm{m}$ & 13.05 & 12.40 & 12.65 & 12.70 & 10.85 & 10.73 \\
\hline & $S_{\mathrm{t}}, \mu \mathrm{m}$ & 111.00 & 96.70 & 95.15 & 100.95 & 84.25 & 84.10 \\
\hline & $S_{\mathrm{z}}, \mu \mathrm{m}$ & 110.50 & 96.20 & 94.90 & 100.53 & 84.05 & 83.65 \\
\hline \multirow{4}{*}{$\begin{array}{l}\text { Parameters of the waviness area } \\
\text { Parametri valova površine }\end{array}$} & $S_{\mathrm{a}}, \mu \mathrm{m}$ & 4.29 & 3.78 & 3.71 & 3.54 & 4.06 & 4.95 \\
\hline & $S_{\mathrm{q}}, \mu \mathrm{m}$ & 5.66 & 4.83 & 4.61 & 4.45 & 4.92 & 6.32 \\
\hline & $S_{\mathrm{t}}, \mu \mathrm{m}$ & 46.85 & 35.20 & 35.90 & 32.80 & 33.65 & 48.60 \\
\hline & $S_{\mathrm{z}}, \mu \mathrm{m}$ & 37.20 & 29.60 & 28.65 & 26.85 & 27.35 & 36.90 \\
\hline \multicolumn{8}{|c|}{ Filter 0.8 / Filtar 0,8} \\
\hline \multirow{5}{*}{$\begin{array}{l}\text { Roughness parameters } \\
\text { Parametri hrapavosti }\end{array}$} & $R_{\mathrm{a}}, \mu \mathrm{m}$ & 2.05 & 2.78 & 3.06 & 2.40 & 1.92 & 2.66 \\
\hline & $R_{\mathrm{q}}, \mu \mathrm{m}$ & 2.55 & 3.49 & 3.81 & 3.00 & 2.38 & 3.30 \\
\hline & $R_{\mathrm{t}}, \mu \mathrm{m}$ & 20.43 & 23.88 & 27.33 & 21.75 & 16.78 & 22.75 \\
\hline & $R_{\mathrm{z}}, \mu \mathrm{m}$ & 10.28 & 13.85 & 15.23 & 11.68 & 9.66 & 13.24 \\
\hline & $R S_{\mathrm{m}}, \mathrm{mm}$ & 0.30 & 0.31 & 0.30 & 0.29 & 0.29 & 0.27 \\
\hline \multirow{5}{*}{$\begin{array}{l}\text { Waviness parameters } \\
\text { Parametri valovitosti }\end{array}$} & $W_{\mathrm{a}}, \mu \mathrm{m}$ & 4.00 & 4.27 & 4.36 & 3.32 & 2.83 & 4.46 \\
\hline & $W_{\mathrm{q}}, \mu \mathrm{m}$ & 4.44 & 4.76 & 4.87 & 3.77 & 3.20 & 4.97 \\
\hline & $W_{\mathrm{t}}, \mu \mathrm{m}$ & 22.30 & 25.32 & 21.75 & 19.55 & 16.32 & 23.10 \\
\hline & $W_{z}, \mu \mathrm{m}$ & 7.67 & 9.07 & 9.11 & 7.34 & 6.23 & 8.82 \\
\hline & $W S_{\mathrm{m}}, \mathrm{mm}$ & 2.00 & 1.73 & 2.01 & 1.62 & 1.67 & 1.94 \\
\hline \multicolumn{8}{|c|}{ Filter 2.5 / Filtar 2,5 } \\
\hline \multirow{5}{*}{$\begin{array}{l}\text { Roughness parameters } \\
\text { Parametri hrapavosti }\end{array}$} & $R_{\mathrm{a}}, \mu \mathrm{m}$ & 3.54 & 4.78 & 4.62 & 3.73 & 3.05 & 4.06 \\
\hline & $R_{\mathrm{q}}, \mu \mathrm{m}$ & 4.45 & 6.04 & 5.72 & 4.79 & 3.79 & 5.02 \\
\hline & $R_{\mathrm{t}}, \mu \mathrm{m}$ & 24.80 & 29.33 & 30.97 & 26.07 & 20.27 & 27.43 \\
\hline & $R_{\mathrm{z}}, \mu \mathrm{m}$ & 12.67 & 25.88 & 24.73 & 21.18 & 15.88 & 21.38 \\
\hline & $R S_{\mathrm{m}}, \mathrm{mm}$ & 7.09 & 0.51 & 0.41 & 0.54 & 0.45 & 0.41 \\
\hline \multirow{5}{*}{$\begin{array}{l}\text { Waviness parameters } \\
\text { Parametri valovitosti }\end{array}$} & $W_{\mathrm{a}}, \mu \mathrm{m}$ & 2.81 & 2.47 & 2.50 & 1.96 & 1.71 & 2.93 \\
\hline & $W_{\mathrm{q}}, \mu \mathrm{m}$ & 3.19 & 2.87 & 2.91 & 2.32 & 1.98 & 3.41 \\
\hline & $W_{\mathrm{t}}, \mu \mathrm{m}$ & 11.40 & 11.60 & 11.20 & 9.87 & 7.18 & 12.74 \\
\hline & $W_{z}, \mu \mathrm{m}$ & 7.57 & 7.06 & 6.75 & 6.41 & 5.32 & 9.14 \\
\hline & $W S_{\mathrm{m}}, \mathrm{mm}$ & 3.29 & 2.96 & 3.47 & 3.21 & 2.92 & 3.18 \\
\hline
\end{tabular}

Legend / Legenda: $S, R, W$ - the mean arithmetical deviation of a profile / srednje aritmetičko odstupanje profila, $\mu \mathrm{m} ; S_{,}, R, W$ - the mean quadratic deviation of a profile / srednje kvadratno odstupanje profila, $\mu \mathrm{m} ; S_{\mathrm{t}}, R_{\mathrm{t}}, W_{\mathrm{t}}$ - the total profile height / ukupna visina profila, $\mu \mathrm{m} ; S_{z}$, $R_{z}, W_{\mathrm{z}}$ - the largest height of a profile / najveća visina profila, $\mu \mathrm{m} ; R S_{\mathrm{m}}, W S_{\mathrm{m}}$ - the mean width of a profile / srednja širina profila, $\mathrm{mm}$

$2.831 \mu \mathrm{m}$ at $10000 \mathrm{~min}^{-1}$ in spruce and from $3.50 \mu \mathrm{m}$ at $9000 \mathrm{~min}^{-1}$ to $4.56 \mu \mathrm{m}$ at $10000 \mathrm{~min}^{-1}$ in beech. The mean quadratic deviation of the waviness profile $W q$ ranges from 4.76 to $3.20 \mu \mathrm{m}$ in spruce and from 3.93 to $5.18 \mu \mathrm{m}$ in beech. With the decreasing feed per tooth these values diminish and, vice versa, with the increasing feed per tooth these values increase.

The average arithmetic deviation of parameters of waviness $W_{\mathrm{a}}$ is the most common parameter in industry. It refers to a stable parameter not affected by accidental changes. The average quadratic deviation of the waviness profile $W_{\mathrm{q}}$ shows a foregrounding effect on particular or accidental projections and depressions. Therefore, it is a parameter that enables the differentiation between very fine surface and similar surface with traces and defects that are not typical. In our case, it rather determines extreme values of waviness. This parameter corresponds to the theoretical calculation of the waviness depth. However, theoretical values of waviness are about $2 \mu \mathrm{m}$ smaller. The total height of the waviness profile $W_{\mathrm{t}}$ is the maximum distance between the profile projection and hollow, i.e. their extreme limits. Particular measurements failed to show the dependence of $W_{\mathrm{t}}$ on parameters of high-speed milling. The measured average values $W_{\mathrm{t}}$ show extreme limits of the profile; however, these are not reliable. The largest profile height $W_{\mathrm{z}}$ ranges from $8.61 \mu \mathrm{m}$ at $9000 \mathrm{~min}^{-1}$ to $7.46 \mu \mathrm{m}$ at 10000 $\mathrm{min}^{-1}$ in spruce and from $9.41 \mu \mathrm{m}$ at $9000 \mathrm{~min}^{-1}$ to 7.62 $\mu \mathrm{m}$ at $10000 \mathrm{~min}^{-1}$ in beech. The average width of the waviness profile $W S_{\mathrm{m}}$ determines the mean width of unevenness. It refers to a very important parameter because its values are often numerically equal to feed per tooth.

Roughness parameters are particularly affected by wood type/species and properties of the machined material. Of course, $R S_{\mathrm{m}}$ parameters can partly determine the distance where torn grain occurs. The average quadratic deviation of the roughness profile $R_{\mathrm{q}}$ differentiates between a typical surface and a surface with non- 
Table 2 Values of roughness and waviness of experimental beech-wood samples

Tablica 2. Vrijednosti hrapavosti i valovitosti za uzorke od bukovine

\begin{tabular}{|c|c|c|c|c|c|c|c|}
\hline \multicolumn{8}{|c|}{ Beech-wood samples / Uzorci od bukovine } \\
\hline \multirow{2}{*}{\multicolumn{2}{|c|}{$\begin{array}{l}\text { Rotational speed, } \text { min }^{-1} / \text { Brzina vrtnje, } \text { min }^{-1} \\
\text { Feed speed, } \mathbf{m} / \mathbf{m i n} \text { / Posmična brzina, } \mathrm{m} / \mathrm{min}\end{array}$}} & \multicolumn{3}{|c|}{$9000 \mathrm{~min}^{-1}$} & \multicolumn{3}{|c|}{$10000 \mathrm{~min}^{-1}$} \\
\hline & & 18 & 20 & 22 & 18 & 20 & 22 \\
\hline \multirow{4}{*}{$\begin{array}{l}\text { Parameters of the basic area } \\
\text { Parametri osnovne površine }\end{array}$} & $S_{\mathrm{a}} \cdot \mu \mathrm{m}$ & 11.60 & 10.30 & 10.35 & 9.71 & 10.35 & 9.83 \\
\hline & $S_{q} \cdot \mu \mathrm{m}$ & 15.60 & 14.45 & 14.30 & 13.05 & 14.30 & 14.60 \\
\hline & $S_{t} \cdot \mu \mathrm{m}$ & 109.70 & 102.00 & 105.50 & 93.30 & 107.50 & 108.00 \\
\hline & $S_{\mathrm{z}} \cdot \mu \mathrm{m}$ & 109.05 & 101.5 & 104.95 & 93.00 & 106.50 & 108.00 \\
\hline \multirow{4}{*}{$\begin{array}{l}\text { Parameters of the waviness area } \\
\text { Parametri površine }\end{array}$} & $S_{\mathrm{a}} \cdot \mu \mathrm{m}$ & 6.24 & 4.36 & 4.76 & 4.95 & 4.38 & 4.15 \\
\hline & $S_{\mathrm{a} . \mu \mathrm{m}}$ & 8.23 & 5.48 & 6.00 & 6.27 & 5.48 & 5.13 \\
\hline & $S_{\mathrm{t}} \cdot \mu \mathrm{m}$ & 56.80 & 41.50 & 47.55 & 49.40 & 40.95 & 37.00 \\
\hline & $S_{\mathrm{z}} \cdot \mu \mathrm{m}$ & 45.60 & 34.75 & 32.80 & 39.60 & 34.00 & 33.05 \\
\hline \multicolumn{8}{|c|}{ Filter 0.8 / Filtar 0,8} \\
\hline \multirow{5}{*}{$\begin{array}{l}\text { Roughness parameters } \\
\text { Parametri hrapavosti }\end{array}$} & $R_{\mathrm{a}} \cdot \mu \mathrm{m}$ & 4.81 & 1.88 & 1.90 & 1.72 & 2.09 & 1.87 \\
\hline & $R_{\mathrm{q}} \cdot \mu \mathrm{m}$ & 5.96 & 2.38 & 2.40 & 2.13 & 2.61 & 2.39 \\
\hline & $R_{\mathrm{t}} \cdot \mu \mathrm{m}$ & 38.50 & 19.25 & 19.52 & 16.73 & 18.90 & 20.75 \\
\hline & $R_{\mathrm{z}} \cdot \mu \mathrm{m}$ & 22.60 & 9.57 & 9.62 & 8.49 & 10.29 & 9.59 \\
\hline & $R S_{\mathrm{m}} \cdot \mathrm{mm}$ & 0.35 & 0.33 & 0.29 & 0.31 & 0.33 & 0.31 \\
\hline \multirow{5}{*}{$\begin{array}{l}\text { Waviness parameters } \\
\text { Parametri valovitost } i\end{array}$} & $W_{\mathrm{a}} \cdot \mu \mathrm{m}$ & 6.56 & 3.50 & 4.15 & 3.51 & 4.56 & 3.70 \\
\hline & $W_{q} \cdot \mu \mathrm{m}$ & 7.47 & 3.93 & 4.64 & 3.90 & 5.18 & 4.16 \\
\hline & $W_{\mathrm{t}} \cdot \mu \mathrm{m}$ & 36.18 & 21.03 & 22.98 & 18.07 & 25.33 & 20.72 \\
\hline & $W_{\mathrm{z}} \cdot \mu \mathrm{m}$ & 14.08 & 6.92 & 7.25 & 6.26 & 9.16 & 7.45 \\
\hline & $W S_{\mathrm{m}} \cdot \mathrm{mm}$ & 1.83 & 2.01 & 2.57 & 1.76 & 2.07 & 1.95 \\
\hline \multicolumn{8}{|c|}{ Filter 2.5 / Filtar 2,5} \\
\hline \multirow{5}{*}{$\begin{array}{l}\text { Roughness parameters } \\
\text { Parametri hrapavosti }\end{array}$} & $R_{\mathrm{a}} \cdot \mu \mathrm{m}$ & 6.77 & 3.14 & 3.12 & 3.08 & 4.02 & 3.24 \\
\hline & $R_{\mathrm{q}} \cdot \mu \mathrm{m}$ & 8.79 & 4.05 & 4.00 & 3.82 & 5.12 & 4.28 \\
\hline & $R_{\mathrm{t}} \cdot \mu \mathrm{m}$ & 48.45 & 23.05 & 23.30 & 21.18 & 26.97 & 25.72 \\
\hline & $R_{\mathrm{z}} \cdot \mu \mathrm{m}$ & 39.12 & 18.98 & 18.50 & 17.07 & 22.00 & 20.48 \\
\hline & $R S_{\mathrm{m}} \cdot \mathrm{mm}$ & 0.47 & 0.51 & 2.00 & 0.54 & 0.56 & 0.58 \\
\hline \multirow{5}{*}{$\begin{array}{l}\text { Waviness parameters } \\
\text { Parametri valovitost } i\end{array}$} & $W_{\mathrm{a}} \cdot \mu \mathrm{m}$ & 4.45 & 2.22 & 2.74 & 2.65 & 3.09 & 2.24 \\
\hline & $W_{\mathrm{q}} \cdot \mu \mathrm{m}$ & 5.04 & 2.55 & 3.01 & 2.97 & 3.71 & 2.64 \\
\hline & $W_{\mathrm{t}} \cdot \mu \mathrm{m}$ & 19.20 & 10.20 & 12.60 & 10.34 & 14.42 & 10.41 \\
\hline & $W_{\mathrm{z}} \cdot \mu \mathrm{m}$ & 11.32 & 5.53 & 6.56 & 5.59 & 8.20 & 5.91 \\
\hline & $W S_{\mathrm{m}} \cdot \mathrm{mm}$ & 3.77 & 4.81 & 3.52 & 5.00 & 4.00 & 3.09 \\
\hline
\end{tabular}

typical changes, which is theoretically characterized by torn grain caused by specific knives. The average width of elements of the roughness profile $R S_{\mathrm{m}}$ is numerically equal to the distance of surface waviness tops - the cut of six knives. The measured values $R_{\mathrm{q}}$ range from $3.49 \mu \mathrm{m}$ at $9000 \mathrm{~min}^{-1}$ to $2.38 \mu \mathrm{m}$ at 10000 $\mathrm{min}^{-1}$ in spruce and from $2.38 \mu \mathrm{m}$ at $9000 \mathrm{~min}^{-1}$ to 2.61 $\mu \mathrm{m}$ at $10000 \mathrm{~min}^{-1}$ in beech. Based on the comparison

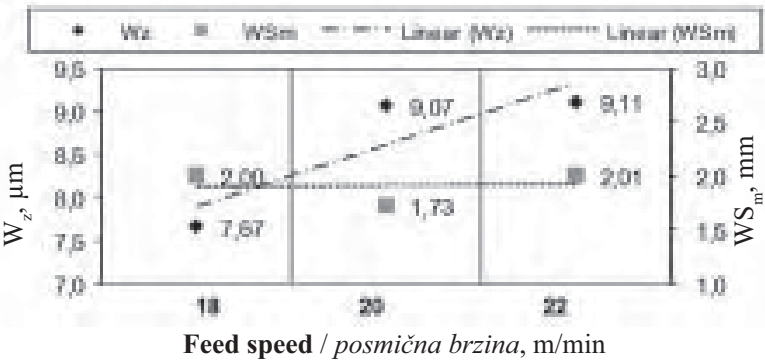

between the results of measurements made by two different Gaussian filters of 0.8 and $2.5 \mathrm{~mm}$, with the use of the $0.8 \mathrm{~mm}$ filter, roughness is suppressed in favour of waviness and, on the contrary, the $2.5 \mathrm{~mm}$ filter released the higher wave length of waviness parameters at the expense of the roughness parameter. It can be concluded that the 2.5 filter is more suitable for assessing waviness than the 0.8 filter.

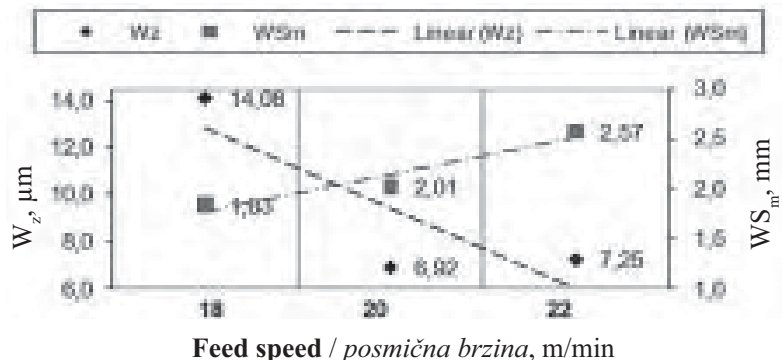

Figure 10 Waviness parameters $W_{\mathrm{z}}$ and $W S_{\mathrm{m}}$ in a function of feed speed while milling spruce (a) and beech (b) samples with the head rotational speed of $9000 \mathrm{~min}^{-1}$

Slika 10. Parametri valovitosti $W_{\mathrm{z}}$ and $W S_{\mathrm{m}}$ u ovisnosti o posmičnoj brzini pri blanjanju smrekovih uzoraka (a) i bukovih uzoraka (b) uz frekvenciju vrtnje alata $9000 \mathrm{~min}^{-1}$ 


\section{CONCLUSIONS}

\section{ZAKLJUČCl}

The measurement of surface quality was carried out by $3 \mathrm{D}$ spatial characteristics that enabled processing of a large number of data. These data then described the assessed profile of the monitored surface. More samples should be measured so as to prove or disprove their dependence. Parameters of high-speed milling were selected with respect to maximum revolutions of ordinary machines. The feed of cut material was chosen in accordance with the requirement to achieve the best possible quality surface. The average quadratic deviation of the waviness profile $W_{\mathrm{q}}$ corresponds to the theoretical calculation of the waviness depth that is, however, about $2 \mu \mathrm{m}$ higher, which can be attributed to the imperfect torn grain that causes "hairy surface". Differences in the $W_{\mathrm{q}}$ parameter among particular species are negligible and the growth of $W_{\mathrm{q}}$ with the feed speed has been confirmed.

The average width of the waviness profile elements $W S_{\mathrm{m}}$ corresponds to the theoretical calculation of the actual distance of the wave tops (one knife cut) particularly for beech; in spruce, the value of $W S_{\mathrm{m}}$ is greater by $0.2 \mathrm{~mm}$, which is affected by the microscopic structure of wood. Samples of spruce showed clearly how differences among early and late wood affected waviness. The growth of $W S_{\mathrm{m}}$ with the increase of feed speed has been proved. With parameters of high-speed milling, 9000 and $10000 \mathrm{~min}^{-1}$, tool edges set to 0.001 $\mathrm{mm}$ and feed of $18 \mathrm{~m} / \mathrm{min}$, it was not possible to fully differentiate the parameter of waviness $W S_{\mathrm{m}}$ because it partly interfered with the roughness parameter $R S_{\mathrm{m}}$. It follows that this surface corresponds to the quality of the ground surface. However, on the milled surface, waviness is partly preserved.

With the other samples, it was also possible to observe waviness caused by the local increase of the wear of knives. With the selected parameters, the final surface quality is particularly affected by the condition and accuracy of knife setting.

Generally, it is possible to determine the following characteristics of the method:

- Parameters used in mechanical engineering can also be partly used for wooden materials.

- It is possible to observe changes during machining.

- It is possible to observe changes in the tool geometry.

- The method enables processing of a large number of data.

\section{REFERENCES}

\section{LITERATURA}

1. Barcík, Š.; Pivolusková, E.; Kminiak,R.; Wieloch, G. 2009: The influence of cutting speed and feed speed on surface quality at plane milling of poplar wood. Wood Research 54 (2): 109-115.
2. Koch, P. 1964: Wood Machining Processen. Ronald Press Company, New York, $530 \mathrm{p}$.

3. Kowalski, M.; Rousek, M.; Cichosz, P.; Karolczak, P. 2008: Modelling the geometrical structure of surface originating in the process of wood milling. Chip and Chipless Woodworking Processes, Štůrovo, 143-148.

4. Lichtág, J. 2003: Progressive technologies of wood machining. Final report of the EUREKA research project No. E!2379TM

5. Lisičan, J. 1996: Teória a technika spracovania dreva (Theory and technology of wood processing) Zvolen, Matcentrum, $625 \mathrm{p}$.

6. Prokeš, S. 1965: Obrábění dřeva a nových hmot ze dřeva. (Machining wood and new wood-based materials). SNTL Praha, 372 p.

7. Sandak, J. 2008: Measuring wood surface roughness without contact. Chip and Chipless Woodworking Processes, Štůrovo, pp. 201-206.

8. Siklienka, M.; Šustek, J.; Hajník, I. 2008: Kvantifikácia nerovnosti povrchu s využitím laserového profilometra pri pílení na horizontálnej pásovej píle. (Quantification of surface roughness using a laser profile-meter at cutting on a horizontal band saw). Chip and Chipless Woodworking Processes, Štůrovo, pp. 207-212.

9. Svoboda, E.; Rousek, M.; Maňas, K.; Kopecký, Z.; Hrubý, V. 2009: Surface structure of milling wood. Annals of Warsaw Agricultural University - SGGW Forestry and Wood Technology, 69: 303-310.

10. Škaljić, N.; Beljo Lučić, R.; Čavlović, A.; Obučina, M. 2009: Effect of Feed Speed and Wood Species on Roughness of Machined Surface. Drvna Industrija, 60 (4): 229234.

11. *** ČSN EN ISO 4287 (1999). Standard - Geometrical demands on products (GPS) - Surface structure: Profile method - Terms, definitions and parameters of the surface structure

12. *** ČSN EN ISO 4288 (1999). Standard - Geometrical demands on products (GPS) - Surface structure: Profile method - Rules and procedures to assess the surface structure

13. ***2010: http//fyzika.fce.vutbr.cz/file/kusak/ konfokalni_mikroskopie.pdf

\section{Acknowledgement - Zahvala}

This paper was prepared in connection with a partial project within the CR MSM 6215648902 Research Plan and IGA project 5/2010 LDF Mendelu. The author thanks for the financial support provided for the project.

\section{Corresponding address:}

Professor MIROSLAV ROUSEK, Ph.D.

Mendel University

Faculty of Forestry and Wood Technology

Zemědělská 3

61300 Brno, CZECH REPUBLIC

e-mail: rousek@mendelu.cz 